\title{
Rancangan DC-DC Converter untuk Penguatan Tegangan
}

\author{
Herman Buntulayuk*1, Faizal Arya Samman ${ }^{1}$, Yusran ${ }^{1}$ \\ ${ }^{1}$ Departemen Teknik Elektro, Fakultas Teknik, Universitas Hasanuddin \\ Jl. Poros Malino Km.6, Bontomarannu, Gowa, Sulawesi Selatan, 92171, Indonesia \\ *Email : hermanbuntulayuk@gmail.com
}

\begin{abstract}
Abstrak
Paper ini menampilkan hasil penelitian kuantitatif, yang bersifat pemodelan simulasi boost converter dengan skenario kontrol PWM untuk mengatur duty cycle dan frekuensi pada sisi masukan, sedangkan pada bagian luaran diberikan pembebanan yang berbeda baik itu beban resistansi, induktansi dan juga kapasitansi. Rangkaian yang digunakan adalah rangkaian penguat teganan dengan metode Dickson. Simulasi juga dilakukan pada beberapa pentahapan mulai dari 2, 3, 4, 6 hingga 8 tahap untuk melihat perubahan besaran tegangan luaran yang dihasilkan. Hasil penelitian menunjukkan bahwa dari 5 jenis pentahapan, tegangan luaran sebesar 1258 Volt diperoleh saat rangkaian dibuat hingga 8 tahap dengan pembebanan resistansi dan kapasitansi dan duty cycle $90 \%$.
\end{abstract}

\begin{abstract}
This paper presents the results of quantitative research, which is modeling simulation boost converter with PWM control scenario to set the duty cycle and frequency at the input side, while at the output is given different loading both the load resistance, inductance and also capacitance. The circuit used is a booster amplifier with Dickson method. Simulations are also done at several stages ranging from 2, 3, 4, 6 to 8 stages to see the changes in the magnitude of the output voltage generated. The results showed that from 5 types of stages, the output voltage of 1258 Volt was obtained when the circuit was made up to 8 stages with loading resistance and capacitance and $90 \%$ duty cycle.
\end{abstract}

Kata kunci : boost converter, metode dickson, kontrol PWM.

\section{Pendahuluan}

Perkembangan teknologi komponen dan rangkaian elektronika telah mampu menghasilkan sistem penyedia daya tegangan searah (Direct Current/DC), yang dihasilkan melalui konversi tegangan DC masukan ke bentuk tegangan DC keluaran yang lebih tinggi atau lebih rendah. Konversi tegangan DC ini biasa disebut sebagai DC-DC converter [1].

Penerapan DC-DC converter dalam perkembangannya telah memungkinkan suatu perangkat elektronika dapat berfungsi dengan menggunakan sumber energi baterai yang bertegangan kecil di mana tegangan keluarannya dapat diubah-ubah sesuai kebutuhan pemakaian [2]. Hingga saat ini, berbagai konfigurasi DCDC converter telah banyak dikembangkan, diantaranya adalah jenis DC-DC converter yang tidak memiliki isolasi dielektrik antara tegangan masukan dan keluaran, atau biasa disebut sebagai non-isolated DC-DC converter [3].
Teknologi konverter elektronika daya telah banyak digunakan pada kehidupan sehari-hari, contoh pengaplikasiannya, DC-DC converter ini digunakan pada sumber energi terbarukan, seperti fuel cell dan solar cell. Dalam aplikasi sumber energi terbarukan, fuel cell dan solar cell menghasilkan tegangan keluaran yang rendah dan ini membutuhkan alat untuk menaikan tegangan [4].

Alat yang umum digunakan sekarang ini adalah DC-DC boost converter. Konverter DCDC ini banyak digunakan untuk aplikasi yang membutuhkan tegangan yang lebih tinggi dari sumbernya. DC-DC boost converter merupakan konverter yang digunakan untuk memberikan tegangan keluaran yang lebih tinggi dari tegangan masukkan yang rendah dengan dikendalikan oleh sinyal kontrol berupa sinyal PWM (Pulse Width Modulation) [5, 6]. 


\section{Deskripsi Permasalahan}

Perkembangan teknologi saat ini mendorong para peneliti untuk mengembangkan pemanfaatan sumber energi terbarukan, dalam hal ini solar cell [7]. Pada penggunaannya energi listrik yang dihasilkan oleh solar cell kemudian disimpan dalam accu sebelum disalurkan ke beban. Masalah yang kemudian muncul adalah, penyimpanan daya dalam accu adalah pada tegangan 12 dan 24 Volt DC sedangkan beberapa beban yang ada membutuhkan tegangan 220 volt ke atas.

Paper ini menampilkan hasil simulasi pemodelan DC-DC converter pada program PSpice [8]. DC-DC converter jenis boost disusun berdasarkan metode Dickson $[9, \quad 10]$. Berdasarkan metode itu simulasi dilakukan pada 5 jenis pentahapan, yakni 2, 3, 4, 6 dan 8 tahap. Simulasi juga dilakukan dengan memberikan pembebanan resistansi, induktansi dan kapasitansi pada rangkaian. Sehingga pada penelitian ini kita melakukan hingga 60 jenis simulasi untuk melihat bagaimana perubahan tegangan luaran yang dihasilkan oleh perubahan variabel tersebut di atas.

\section{Hasil Perancangan}

Simulasi dilakukan dengan terlebih dahulu membuat rangkaian pemodelan yang akan digunakan seperti yang ditunjukkan pada Gambar 1 di bawah :

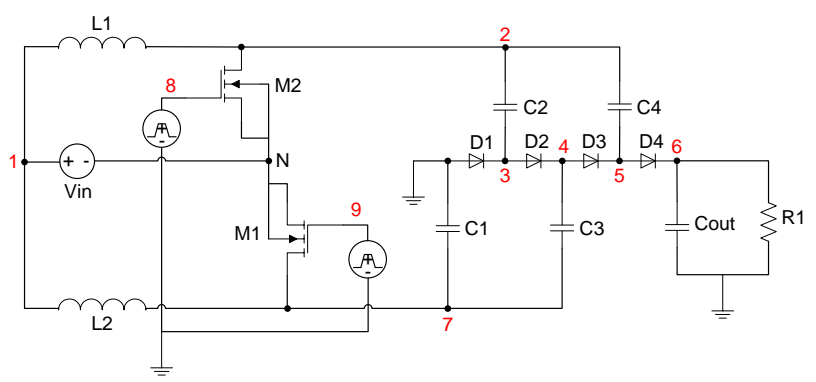
Gambar 1. Rangkaian DC-DC Boost Converter Metode
Dickson

Dari rangkaian dasar yang ditunjukkan pada Gambar 1 tersebut, penelitian dikembangkan dengan penambahan tahap ( 1 tahap $=2$ kapasitor + 2 dioda) pada setiap pemodelan. Untuk rangkaian yang menggunakan metode 3 tahap dapat dilihat pada Gambar 2 di bawah.

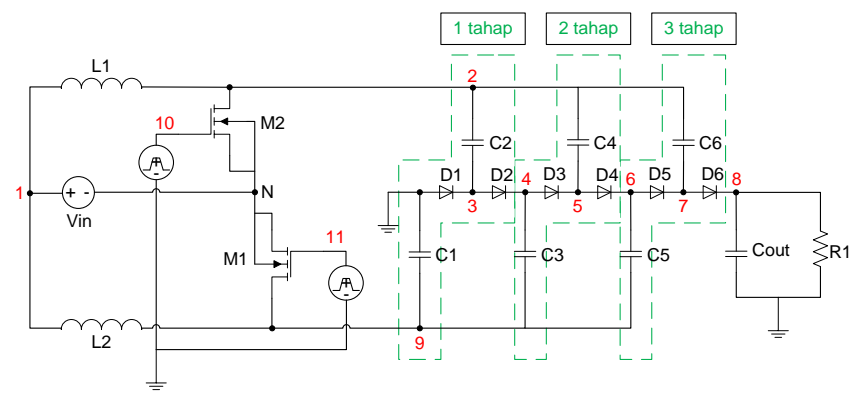

Gambar 2. Rangkaian DC-DC Konverter dengan
Metode Dickson 3 Tahap

Dari rangkaian yang ada kemudian dibuatkan simulasi menggunakan bahasa pemograman PSpice. Nilai parameter yang digunakan pada simulasi ditunjukkan dalam Tabel 1 berikut.

Tabel 1. Nilai Parameter Simulasi

\begin{tabular}{lll}
\hline \multicolumn{1}{c}{ Spesifikasi } & \multicolumn{1}{c}{ Parameter } & \multicolumn{1}{c}{ Nilai } \\
\hline $\begin{array}{l}\text { Tegangan } \\
\text { Input }\end{array}$ & Vin & $12 \mathrm{~V}$ \\
\hline Hambatan & Rload & $400,700,1000 \Omega$ \\
\hline \multirow{2}{*}{ Induktor } & L1, L2 & $100 \mathrm{u} \mathrm{H}$ \\
& Lload & $100 \mathrm{u}, 200 \mathrm{u}, 400 \mathrm{u} \mathrm{H}$ \\
\hline \multirow{3}{*}{ Kapasitor } & Cl, C2, C3, dst & $60 \mathrm{u} \mathrm{F}$ \\
& Cout & $22 \mathrm{u} \mathrm{F}$ \\
& Cload & $200 \mathrm{u}, 400 \mathrm{u}, 800 \mathrm{u} \mathrm{F}$ \\
\hline Frekuensi & Hz & $200 \mathrm{k}, 300 \mathrm{k}, 400 \mathrm{k} \mathrm{Hz}$ \\
\hline Duty Cycle & $D$ & $0.5,0.7,0.9$ \\
\hline
\end{tabular}

Pemberian pembebanan pada setiap pentahapan rangkaian dilakukan bertahap, mulai dari beban resistansi, beban resistansi dan induktansi, beban resistansi dan kapasitansi, dan beban resistansi, induktansi dan kapasitansi, model rangkaiannya ditunjukkan sebagai berikut:

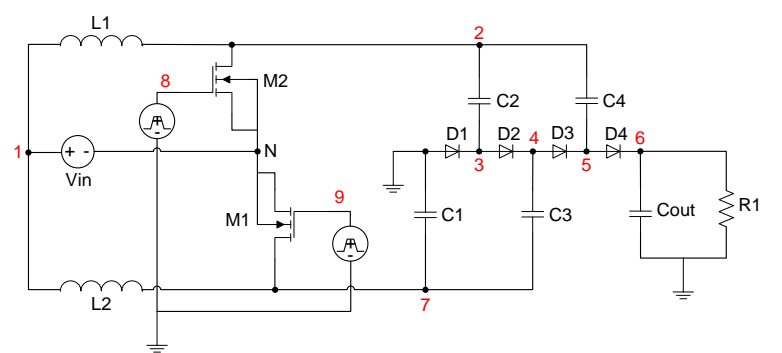

(a) Beban R 


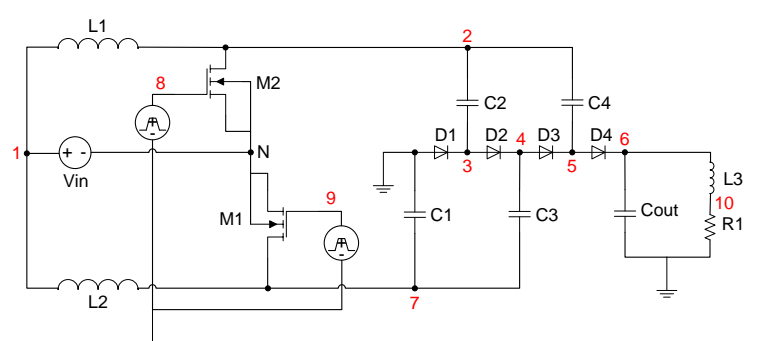

(b) Beban $\mathrm{R}+\mathrm{L}$

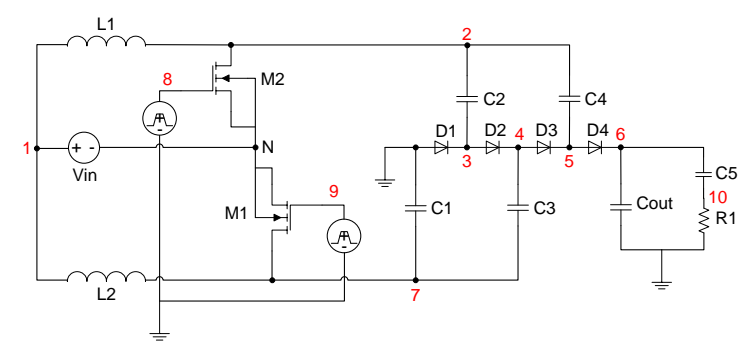

(c) Beban $\mathrm{R}+\mathrm{C}$

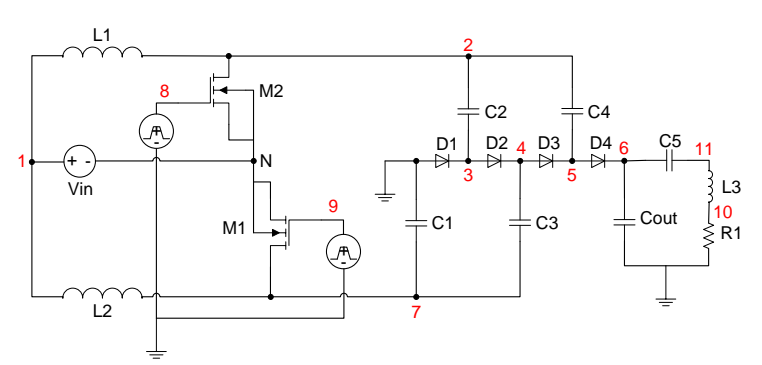

(d) Beban R+L+C

Gambar 3. Variabel pembebanan pada DC-DC Boost Converter

\section{Hasil Simulasi}

Setelah melakukan simulasi pada setiap tahap dan variabel pembebanan kemudian diperoleh data sebagai berikut :

a) Pada simulasi dengan 2 tahap, nilai tegangan luaran tertinggi $\left(\mathrm{V}_{\text {out }}\right)$ sebesar 252 Volt terjadi ketika rangkaian dalam keadaan berbeban resistor, lilitan dan kapasitor dengan nilai $\mathrm{R}=1000 \Omega, \mathrm{L}=100 \mathrm{u} \mathrm{H}, \mathrm{C}=800 \mathrm{u}$ $\mathrm{F}$, pada frekuensi 200k Hz, duty cycle 0.9 dalam waktu $56 \mathrm{~m} \mathrm{~s}$.

b) Simulasi dengan 3 tahap dapat diperoleh tegangan luaran tertinggi pada kondisi steady state dalam kondisi : rangkaian diberikan beban $\mathrm{R}=1000 \Omega$ dan $\mathrm{C}=400 \mathrm{u} \mathrm{F}$ pada frekuensi $200 \mathrm{k} \mathrm{Hz}$ dan duty cycle 0.9 diperoleh tegangan luaran sebesar 380 Volt dalam waktu $100 \mathrm{~m}$ s. c) Simulasi rangkaian DC-DC converter metode Dickson menggunakan 4 tahap diperoleh hasil dimana nilai tegangan luaran tertinggi pada kondisi steady state dapat diperoleh pada kondisi rangkaian diberikan beban $\mathrm{R}=1000 \Omega, \mathrm{L}=100 \mathrm{u} \mathrm{H}, \mathrm{C}=200 \mathrm{u} \mathrm{F}$ pada frekuensi $200 \mathrm{k} \mathrm{Hz}$ dan duty cycle 0.9 diperoleh nilai $\mathrm{V}_{\text {out }}=518$ Volt dalam waktu $150 \mathrm{~ms}$.

d) Simulasi rangkaian DC-DC converter metode Dickson menggunakan 6 tahap diperoleh hasil dimana nilai tegangan luaran tertinggi pada kondisi steady state dapat diperoleh pada kondisi rangkaian diberikan beban $\mathrm{R}=1000 \Omega, \mathrm{L}=100 \mathrm{u} \mathrm{H}, \mathrm{C}=200 \mathrm{u} \mathrm{F}$ pada frekuensi $200 \mathrm{k} \mathrm{Hz}$ dan duty cycle 0.9 diperoleh nilai $\mathrm{V}_{\text {out }}=878$ Volt dalam waktu $100 \mathrm{~ms}$.

e) Simulasi rangkaian DC-DC converter metode Dickson menggunakan 8 tahap diperoleh hasil dimana nilai tegangan luaran tertinggi pada kondisi steady state dapat diperoleh pada kondisi rangkaian diberikan beban $\mathrm{R}=1000 \Omega$ dan $\mathrm{C}=200 \mathrm{u} \mathrm{F}$ pada frekuensi 200k Hz dan duty cycle 0.9 diperoleh nilai $\mathrm{V}_{\text {out }}=1258$ Volt dalam waktu $120 \mathrm{~ms}$. Hasil ini sebenarnya belum dapat dijadikan acuan, karna untuk simulasi menggunakan beban hambatan, induktor dan kapasitor tidak dapat diproses lagi dalam program Pspice.

Sedangkan jika dilakukan analisa data, pengaruh jenis pembebanan terhadap nilai tegangan keluaran pada masing-masing pentahapan, maka akan diperoleh hasil seperti yang ditunjukkan pada beberapa grafik berikut:

\section{BEBAN R}

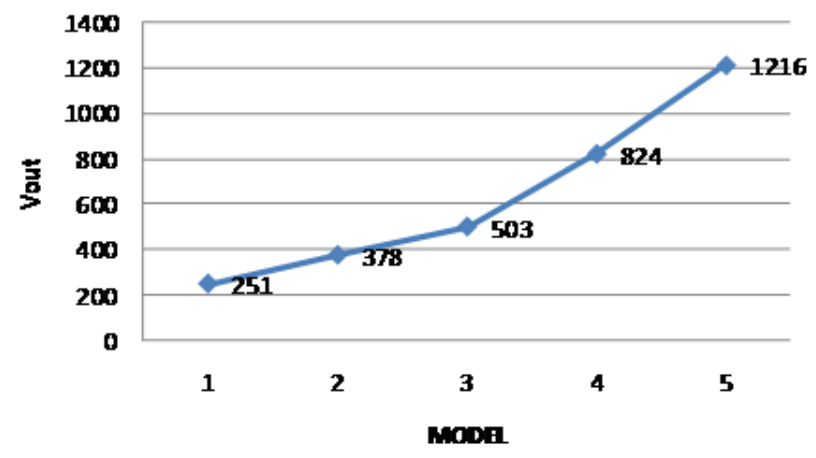

Grafik 1. Tegangan luaran beban $\mathbf{R}$ 
Dari Grafik 1 di atas kita dapat melihat kenaikan nilai $\mathrm{V}_{\text {out }}$ yang dipengaruhi oleh beban resistansi, dimana dengan nilai $\mathrm{R}$ yang tetap yakni $1000 \Omega$ kita dapat memperoleh $\mathrm{V}_{\text {out }}$ pada setiap pentahapan, yakni : 2 tahap $=251$ Volt, 3 tahap $=378$ Volt, 4 tahap $=503$ Volt, 6 tahap $=$ 824 Volt dan 8 tahap $=1216$ Volt.

\section{BEBAN R+L}

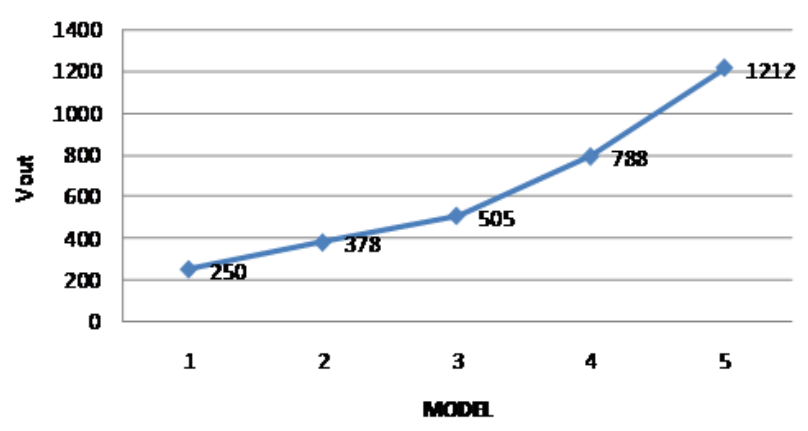

Grafik 2. Tegangan luaran beban $\mathbf{R}+\mathbf{L}$

Jika rangkaian yang sama diberikan beban resistansi dan lilitan, maka kita dapat melihat Vout dari setiap pentahapan pada Grafik 2 di atas, dimana Vout yang dihasilkan rata-rata lebih rendah dibandingkan yang mendapatkan beban resistansi saja, hal ini disebabkan adanya penambahan beban induktansi.

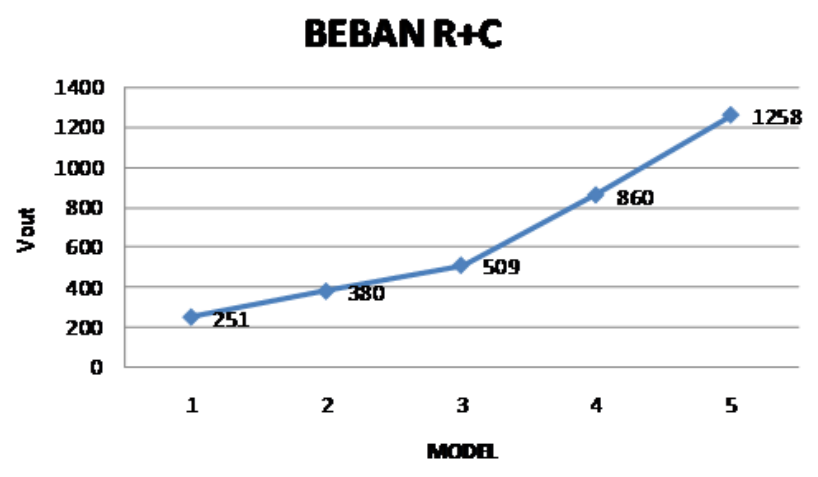

Grafik 3. Tegangan luaran beban $\mathrm{R}+\mathrm{C}$

Dari Grafik 3 di atas kita dapat melihat bagaimana perubahan Vout pada setiap pentahapan, untuk simulasi ini yang menggunakan beban tahanan dan kapasitor diperoleh tegangan luaran yang lebih tinggi jika dibandingkan yang diberikan beban tahanan dan induktansi dan beban resistansi saja.

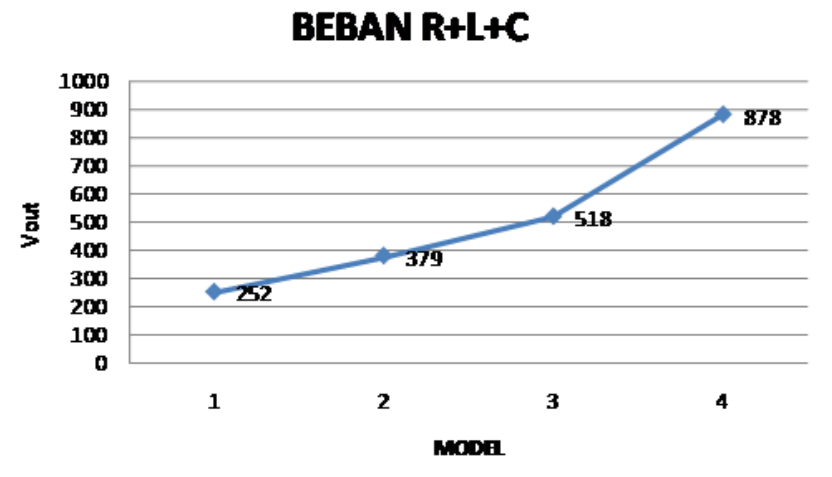

Grafik 4. Tegangan luaran beban $R+L+C$

Sementara itu jika kita melakukan simulasi dengan memberikan beban resistansi, induktansi dan kapasitansi sekaligus dapat kita lihat bahwa nilai tegangan luaran yang dihasilkan untuk setiap pentahapan adalah yang tertinggi jika dibandingkan dengan pembebanan yang lain. Hanya saja untuk simulasi dengan 8 pentahapan tidak dapat diproses lagi oleh Pspice hal ini bisa dikarenakan karna banyaknya data yang diperoleh.

\section{Kesimpulan}

Kesimpulan yang dapat kita ambil dari penelitian ini adalah sebagai berikut :

a) Simulasi DC-DC Boost Converter dengan menggunakan Metode Dickson pada aplikasi PSpice dapat diperoleh nilai tegangan luaran 1258 Volt dari tegangan masukan 12 Volt, dengan menggunakan 8 pentahapan yang diberikan beban tahanan dan kapasitor.

b) Pengontrolan PWM yakni pengaturan duty cycle pada sisi masukan, dapat mempengaruhi tegangan luaran yang dihasilkan, yakni semakin besar nilai duty cycle nya maka semakin besar tegangan luaran yang dihasilkan.

c) Pemberian beban induktansi pada rangkaian dapat menurunkan nilai tegangan luaran, untuk mencegahnya dapat diberikan beban kapasitansi. 


\section{Referensi}

[1] Forsyth, A.J., and Mollov, S.V., "Modelling and Control of DC-DC Converters", Power Engineering Journal, pp. 229-236, 1998.

[2] Noor. Nirwan A., Faizal Arya Samman, and Yusri Syam Akil, "Studi Perbandingan Kinerja Konverter DC-DC Penaik Tegangan Jenis-Jenis DC Chopper dan Charge Pump Multi-Stage", Jurnal Prosiding, ISBN: 978-602-72676-3-3, pp. 33-39, 2015.

[3] Siddique, Md Rifat Alam, and Ferdous Md Jannatul, "Charge Pump Capacitor Based High Voltage Gain DC-DC Step-Up Converter", IEEE, 978-1-4799-51802/14, 2014.

[4] Md. Rifat Alam Siddique, Md. Jannatul Ferdous, Istiaque Islam, "Charge Pump Capacitor Based High Voltage Gain DC-DC StepUp Converter", ICIEV, IEEE Conference Publications, pp. 1-4, 2014.

[5] Gendroyono, and Purwanto, "Sistem Penggerak Motor Induksi dengan Beban Berubah Menggunakan Inverter PWM Berbasis Mikrokontroler", Program Pascasarjana Universitas Gadjah Mada, 1999.
[6] V. A. K. Prabhala, P. Fajri, V. S. P. Gouribhatla, B. P. Baddipadiga, and M. Ferdowsi, "A DC-DC Converter With High Voltage Gain and Two Input Boost Stages", Power Electronics, IEEE Transactions, vol. 31, pp. 4206-4215, 2016.

[7] W. Bin, L. Shouxiang, L. Yao, and K. M. Smedley, "A New Hybrid Boosting Converter for Renewable Energy Applications", Power Electronics, IEEE Transactions, vol. 31, pp. 1203-1215, 2016.

[8] Muhammad H. Rashid, Hasan M. Rashid, "SPICE For Power Electronics And Electric Power", Taylor and Francis Group, Second Edition, USA, 2006.

[9] Ahmad Alzahrani, Pourya Shamsi, Mehdi Ferdowsi, "Analysis and Design of Bipolar Dickson DCDC Converter", PECI, IEEE Conference Publications, pp. 1-6, 2017.

[10]B. P. Baddipadiga, and M. Ferdowsi, "A High Voltage Gain DC-DC Converter Based on Modified Dickson Charge Pump Voltage Multiplier. 